\title{
Technological Approaches to Cider Quality
}

\author{
Kolobaeva Anna \\ Faculty of Technology and Merchandizing \\ Voronezh State Agrarian University \\ Voronezh, Russia \\ kolobaevaanna@yandex.ru
}

\author{
Kotik Olga \\ Faculty of Technology and Merchandizing \\ Voronezh State Agrarian University \\ Voronezh, Russia \\ kotik-oa@yandex.ru
}

\begin{abstract}
The purpose of the study was to determine key parameters influencing the quality of cider. Six apple grades of different ripeness period were considered: Ulyanishchev's Memory, Berkutovskoye, Ligol, Rossoshanskoye Striped, Bogatyr, and Lobo. All fruits were grown in the pomological garden of Voronezh State Agrarian University. The chemical composition of apples and the produced juice was determined. It was found that the sugar content is higher in such apple grades as Ulyanishchev's Memory, Rossoshanskoye Striped and Berkutovskoye. The mass fraction of titratable acids was higher for Ligol and Bogatyr grades. The tannin content was critical in the production of cider. Its largest content was noted in juice made of Ligol apples - $579 \mathrm{mg} / 100 \mathrm{~g}$. Ulyanishchev's Memory, Berkutovskoye, Rossoshanskoye Striped and Ligol were characterized by higher content of antioxidants. Such yeasts as Lalvin ICV-D 47, EC-1118, 71V-1122, V 116 were chosen for the study. It was found that the Lalvin EC-1118 had the highest quality. During the fermentation of apple must the solids content was defined every two days within ten days. It was established that in case of Ulyanishchev's Memory, Ligol, Rossoshanskoye Striped grades the decrease rate of solids was higher and favored the development of yeast cells. The organoleptic analysis made it possible to determine the correlation of juice in a blend. The blend options with juice content ranging from 40 to $60 \%$ had the maximum score.
\end{abstract}

Keywords—cider, yeast, tannin, antioxidants, apples.

\section{INTRODUCTION}

The quality of food, including beverages, is considered the most important element of the people's health. Being a complex indicator, the quality includes such elements as nutrition, energy and biological value, as well as sensorical aspects. The majority of consumers understand quality as food naturality and its positive influence on a human body. According to the general international practice the food producers are obliged to satisfy only one quality indicator safety. However, to make products meeting modern requirements there is a need to ensure the compliance with various conditions at all production stages.

The raw materials influence the quality features of final products. Currently, food enterprises are trying to replace natural ingredients with artificial or processed ones, which adversely affect the usefulness of products on human health. This is particularly important in the production of cider. The use of reconstituted import juice, which occupies at least $90 \%$ of the Russian market, leads to decrease of vitamins, antioxidants and other biologically active agents in final products [1]. Hence, the production of modern high-quality cider is only possible using the freshly pressed juice.

Cider production is an upcoming trend from the perspective of both economy and the production of functional food. The study showed considerable accumulation of organic acids and other substances. Thus, it was determined that the final product is rich in thyrozol - natural antioxidant usually coming from olive oil [2]

Due to historically developed traditions of apple consumption in Russia, there is not enough data on the suitability of various apple grades for cider production in our country. In the conditions of considerable raw reserves, only their small part is used for the production of fruit wines. Cider grades significantly differ from standard apples (eating and dessert) by their pulp structure, as well as physical and chemical parameters - much higher mass concentration of phenolic substances and sugars and lower concentration of titratable acids.

The study of apple composition from various regions [3-7] shows that the accumulation intensity of acids, phenolic substances and sugars significantly differs depending on grade, soils and climatic conditions. It also demonstrates the advisability of juice blending from various apple grades [8]. There are some data on various localization substances in apple fruits indicating their antioxidant activity and influence of fruit color on the considered indicator [9]. Hence, there is a need to develop recommendations on the use of apple grades grown in various regions of the country.

The type of microorganisms is a very important factor influencing the quality of cider [10-12]. Yeast of various producers and races result in different taste and flavor. The fermentation time, temperature and dynamics of must indicators change are technologically important [13-15].

\section{OBJECTS AND METHODS}

The object of the study covered apple grades of medium and late ripeness of 2017, i.e. Ulyanishchev's Memory, Berkutovskoye, Ligol, Rossoshanskoye Striped, Bogatyr, recommended for the Central Chernozem region of Russia. All fruits were grown in the pomological garden of Voronezh State Agrarian University. Such yeasts as Lalvin ICV-D 47, EC-1118, 71V-1122, V 116 were chosen for the study. The 
sugar syrup and glycose-fructose syrup were used according to the current standard documentation.

The solids content was determined via the refractometric method [16], the weight fraction of titratable acids - through titration [17], the antioxidant activity - via the amperometric technique proposed by KHIMAVTOMATIKA Research Company [18]. The content of phosphorus was determined by vanadium molybdate method, calcium - by trilon method, sugar - by standardized technique [19], tannin - by spectrophotometric analysis [20]. The yeast was studied via the microscopic analysis [21]. Organoleptic characteristics of cider were assessed in points [22]. The process conditions were optimized via mathematical experimental design and statistical data processing [23]

\section{RESULTS AND DISCUSSION}

First, the study covered the analysis of apple raw materials. The following indicators were defined: content of solids, total sugar, vitamins, mineral nutrients, tannins, acidity and juice extraction. The choice of indicators is caused by their importance in the technological process and their direct influence on the biological value of cider.

Table 1 shows the results of the analysis of apple fruits regarding the studied grades.

According to the obtained data, the studied indicators differ for different grades of apples. The dry solids weight ratio varied from 12.36 to $15.18 \%$, which corresponds to the average values given in reference sources. Insignificant difference in indicators may be explained by similar edaphoclimatic conditions of apple cultivation.

TABLE I. CHEMICAL COMPOSITION OF APPLES

\begin{tabular}{|l|c|c|c|c|c|}
\hline \multicolumn{1}{|c|}{ Grade } & $\begin{array}{c}\text { Dry solids } \\
\text { weight ratio, } \\
\mathbf{\%}\end{array}$ & $\begin{array}{c}\text { Vitamin C } \\
\text { content, } \\
\mathbf{m g} / \mathbf{1 0 0} \mathbf{g}\end{array}$ & $\begin{array}{c}\text { Total sugar, } \\
\mathbf{\%}\end{array}$ & $\begin{array}{c}\text { Mass fraction of titratable } \\
\text { acids, \% }\end{array}$ & P/Ca content, \% \\
\hline $\begin{array}{l}\text { Ulyanishchev's } \\
\text { Memory }\end{array}$ & 14.02 & 16.12 & 14.20 & 0.47 & $0.022 / 0.009$ \\
\hline Berkutovskoye & 15.18 & 14.36 & 13.00 & 0.41 & $0.014 / 0.006$ \\
\hline Ligol & 14.08 & 6.80 & 11.16 & 0.54 & $0.010 / 0.007$ \\
\hline $\begin{array}{l}\text { Rossoshanskoye } \\
\text { Striped }\end{array}$ & 15.11 & 19.54 & 13.10 & 0.44 & $0.012 / 0.008$ \\
\hline Bogatyr & 12.36 & 3.54 & 10.11 & 0.56 & $0.017 / 0.008$ \\
\hline Lobo & 13.57 & 3.52 & 9.30 & 0.49 & $0.017 / 0.007$ \\
\hline
\end{tabular}

The content of vitamin $\mathrm{C}$ considerably differed for apples of different grades. It is found that Ulyanishchev's Memory and Rossoshanskoye Striped have the highest value - 16.12 and $19.54 \mathrm{mg} / 100 \mathrm{~g}$ respectively. In cider production, the vitamins are generally transformed into a final product. Therefore, the use of raw materials rich in vitamins is preferable.

The content of sugars and acids affects the fermentation of apple must. In case of poor nutrition, the process is slow and can be ceased. Such apple grades as Ulyanishchev's Memory, Rossoshanskoye Striped and Berkutovsky had the highest sugar content.

The studied samples are characterized by the content of phosphorus and calcium. Mineral nutrients are necessary yeast feeding sources. Besides, they improve the biological value of a product.

Table 2 shows the results of the analysis of apple juice regarding the studied grades.

It is recommended to use apples with high juice extraction ratio in cider production. Among the considered samples the highest values were defined in Lobo $-74 \%$ and Ulyanishchev's Memory $-66.3 \%$.

The specific indicator defining suitability of apples for cider production is the tannin content. High concentration of this component is the least subjected to weather conditions and is mainly defined by the grade. Tannin influences the race of apple and grape wines, forms characteristic astringent flavor, participates in fermentation and ensures long storage of beverages. According to the obtained data, the juice of the Ligol grade has the highest tannin content $-579 \mathrm{mg} / 100 \mathrm{~g}$. Hence, it is more preferable regarding the considered criterion.

TABLE II. QUALITY INDICATORS OF APPLE JUICE

\begin{tabular}{|l|c|c|c|}
\hline \multicolumn{1}{|c|}{ Grade } & $\begin{array}{c}\text { Juice } \\
\text { extraction, } \\
\mathbf{\%}\end{array}$ & $\begin{array}{c}\text { Tannin } \\
\text { content, } \\
\mathbf{m g} / \mathbf{1 0 0} \mathbf{g}\end{array}$ & $\begin{array}{c}\text { Antioxidant } \\
\text { content, } \\
\mathbf{m g} / \mathbf{d m}^{3}\end{array}$ \\
\hline $\begin{array}{l}\text { Ulyanishchev's } \\
\text { Memory }\end{array}$ & 66.3 & 320 & 458.60 \\
\hline Berkutovskoye & 58.8 & 234 & 459.38 \\
\hline Ligol & 63.1 & 579 & 440.11 \\
\hline $\begin{array}{l}\text { Rossoshanskoye } \\
\text { Striped }\end{array}$ & 60.4 & 407 & 462.18 \\
\hline Bogatyr & 59.3 & 352 & 290.21 \\
\hline Lobo & 74 & 340 & 305.34 \\
\hline
\end{tabular}

The content of antioxidants is a complex indicator, which depends on the content of vitamins, phenolic compounds and other substances demonstrating antioxidant properties in apple juice. Among the studied apple grades, the Bogatyr and Lobo have the smallest indicator. Ulyanishchev's Memory, Berkutovskoye, Rossoshanskoye Striped and Ligol have higher content of antioxidants. It is possible to consider the dependence of antioxidants content on fruit color among the considered samples. 
The following stage of study included the analysis of yeasts available in the market and recommended for the production of fruit wines. Table 3 shows the obtained results.

TABLE III. MICROBIOLOGICAL CHARACTERISTICS OF LALVIN YEAST

\begin{tabular}{|l|c|c|c|c|}
\hline \multicolumn{1}{|c|}{ Indicator } & $\begin{array}{l}\text { ICV-D } \\
\mathbf{4 7}\end{array}$ & $\begin{array}{l}\text { EC- } \\
\mathbf{1 1 1 8}\end{array}$ & $\begin{array}{l}\mathbf{7 1 B}- \\
\mathbf{1 1 2 2}\end{array}$ & V 1116 \\
\hline CFU, cm ${ }^{3}$ & $4 \cdot 10^{7}$ & $3 \cdot 10^{7}$ & $7 \cdot 10^{7}$ & $8 \cdot 10^{6}$ \\
\hline $\begin{array}{l}\text { Number of } \\
\text { glycogen-rich cells, } \\
\%\end{array}$ & 50 & 52 & 62 & 54 \\
\hline $\begin{array}{l}\text { Number of dead } \\
\text { cells, \% }\end{array}$ & 2 & 2.3 & 0.9 & 3 \\
\hline $\begin{array}{l}\text { Number of budding } \\
\text { cells, \% }\end{array}$ & 38 & 41 & 46 & 39 \\
\hline
\end{tabular}

Table 3 shows that all yeast samples correspond to qualifying requirements. The Lalvin $71 \mathrm{~V}-1122$ yeast has the highest number of glycogen-rich and budding cells, and the smallest number of dead cells. It was decided to further study the specified yeast brand.

Fig. 1 shows the dynamics of solids content in apple must when different apple grades are used.

The top quality production requires the use of apple grades ensuring normal yeast forming. The decrease rate of solids can be used as a vital factor of yeast cells.

The solids content in a must was defined every two days within ten days. The apple must, produced from such apple grades as Ulyanishchev's Memory, Berkutovskoye, Ligol and Rossoshanskoye Striped, is characterized by intense fermentation and higher decrease rate of solids.

The intense fermentation of Berkutovsky must stopped in 8 days. In case with Lobo and Bogatyr grades, the fermentation was slow and the solids content exceeded $4 \%$ in 10 days.

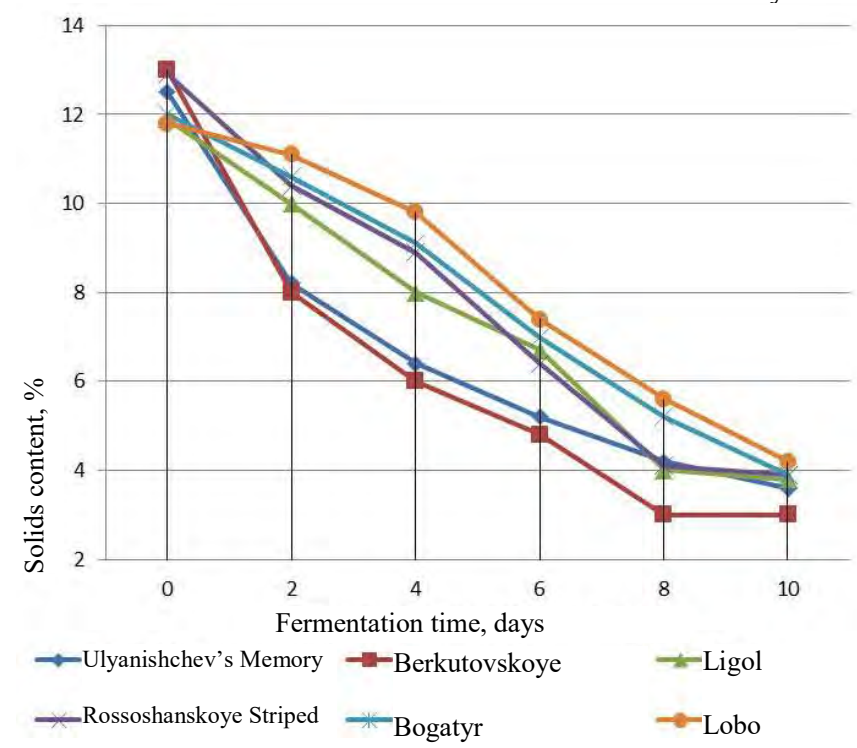

Fig. 1. Dependence of solids content in a must on fermentation time and apple grade

The analysis of the chemical composition of apple fruits and the dynamics of must fermentation makes it possible to conclude that the Ulyanishchev's Memory and Ligol grades are more advisable for use.
The organoleptic analysis of matured cider was used to establish the correlation of juice in a blend. The juice of Ulyanishchev's Memory grade was taken as a basis. The dosage of Ligol apple juice varied from 20 to $100 \%$. Organoleptic characteristics of cider were assessed in points. Figure 2 shows the results of the study.

The blend options with Ligol juice content from 40 to $60 \%$ have the maximum score. The samples containing less than $40 \%$ are characterized by the general decrease of indicators, deterioration of flavor, and bland flavor. The increase in blend content of Ligol juice by more than $60 \%$ also decreased the general score.

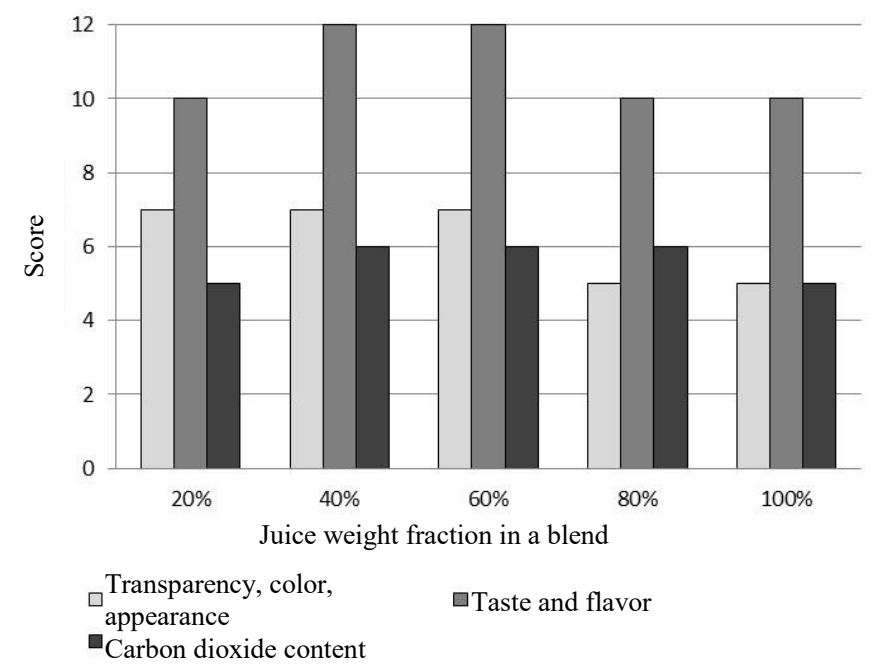

Fig. 2. Quality score of cider

The optimization of process parameters included the study of such factors influencing the content of solids (V) as the Ligol juice dosage in a blend (x), yeast dosage (y) and must fermentation temperature (z). The complete factorial experiment $3^{3}$ was chosen for the study. The obtained model is presented by the following equation:

$$
V=4.52-0.93 x-0.03 x^{2}-0.17 y-0.09 y^{2}-0.19 z-0.01 z^{2}
$$

The negative regression coefficients indicate the reverse influence of the considered variables on the content of cider solids within the studied range of values.

Figure 3 shows the dependence of solids content on juice and yeast dosage in a blend. Moreover, the average must fermentation temperature is taken as $28{ }^{\circ} \mathrm{C}$. The presented leaf-shaped surface is considerably inclined along the $y$ axis, and hence, the 'juice dosage' indicator affects the solids content. The change of yeast dosage does not influence much the dependent variable.

Figure 4 shows the same leaf-shaped dependence of solids content on must fermentation temperature and yeast dosage. However, the surface is placed horizontally with a slight inclination, which may be explained by minor influence of the specified factors on the solids content.

The study makes it possible to conclude that the minimum dependent variable is achieved at the maximum variables within the considered range of values. 


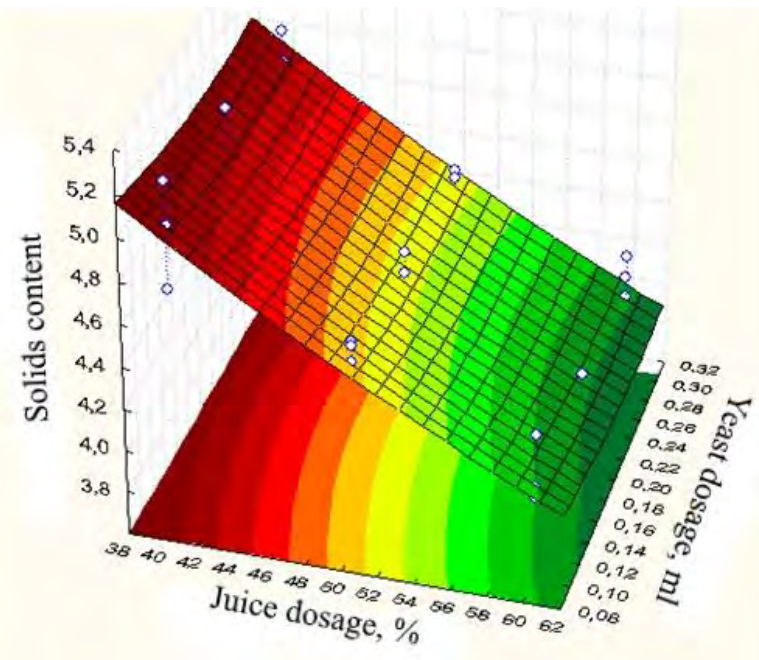

Fig. 3. Dependence of solids content on juice and yeast dosage

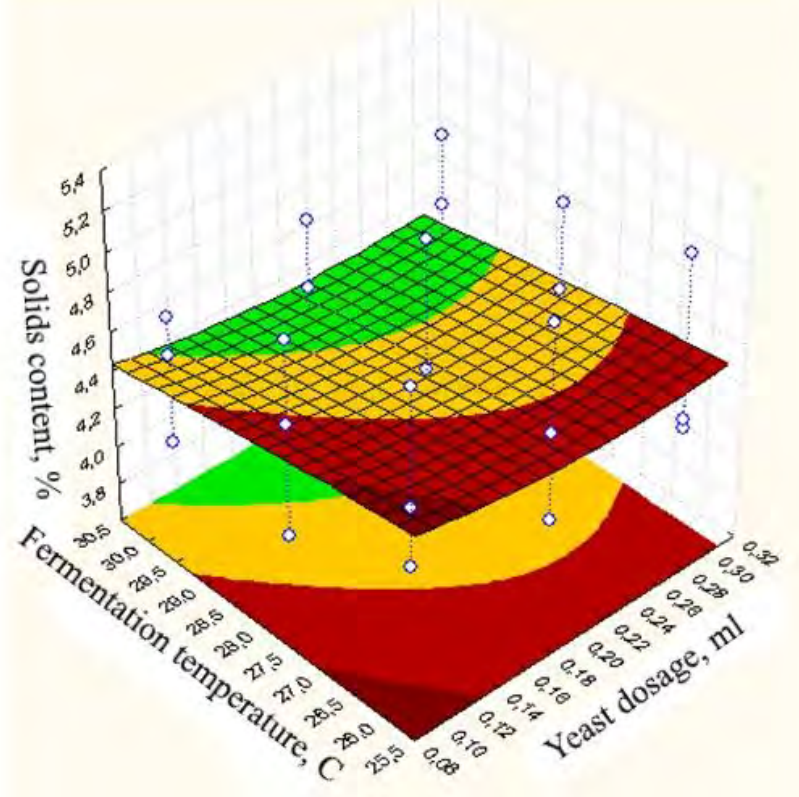

Fig. 4. Dependence of solids content on fermentation temperature and yeast dosage

Thus, the main technological stages influencing the quality of cider were established. The study of different apple grades registered in the Central Chernozem region of Russia made it possible to identify grades suitable for cider production. The blend from Ulyanishchev's Memory and Ligol grades ensuring high taste was selected. The Lalvin $71 \mathrm{~V}-1122$ yeast was recommended based on microbiological study. The optimal process parameters are established: Ligol juice content in a blend $-60 \%$, must fermentation temperature $-30{ }^{\circ} \mathrm{C}$.

\section{References}

[1] N.I. Usenko, V.M. Poznyakovsky, A.G. Olovyanishnikov, Myths on quality (peculiarities of modern industrial food production), EKO. 2013, No. 6 (468), pp. 133-148.
[2] E. Cusano, B. Simonato, R. Consonni, Fermentation process of apple juice investigated by NMR spectroscopy, LWT - Food Science and Technology, Volume 96, October 2018, pp. 147-151.

[3] A.A. Shirshova, A.R. Blyagoz, N.M. Ageeva, E.A. Sosyura, Influence of chemical composition of apple grades on physical and chemical indicators of fermented juice for the production of fruit wines. A.A. Shirshova, Messenger of Stavropol Agrarian and Industrial Complex. Stavropol: Stavropol State Agricultural University, 2016, No. 2(22), pp. 45-49.

[4] V.I. Voytsekhovsky, A.E. Tokar, M.B. Rebezov, Quality of cider wine materials depending on apple grade and yeast race, Messenger of the Southern Ural State University. Series: Food Biotechnologies. Chelyabinsk: SUSU Publishing center, 2014, V.2, No. 4, pp. 42-49.

[5] A.A. Kolobayeva, N.V. Korolkova, O.A. Kotik, I.A. Sorokina, E.V. Panina, A.A. Rtishchev, Cider from local raw materials of the Central Chernozem Region, Food industry, 2017, No. 11, pp. 48-51.

[6] N.V. Makarova, D.F. Valiulina, O.I. Azarov, A.A. Kuznetsov, Comparative study of phenolic compounds, flavonoids and antioxidant activity of apples of different grades, Chemistry of vegetable raw materials, No. 2, pp. 115-122, 2018.

[7] Satora Pawel; Sroka, Pawel; Duda-Chodak, Aleksandra; et al., The profile of volatile compounds and polyphenols in wines produced from dessert varieties of apples, FOOD CHEMISTRY, V. 111, Issue 2, pp. 513-519, NOV 152008.

[8] E. Vangdal, K. Kvamm-Lichtenfeld, Ciders produced from Norwegian fresh consumption apple cultivars, Acta Horticulturae, Volume 1205, 30 June 2018. pp. 527-531.

[9] I. Smetanska, J. Helfert, U. Appeltauer-Brandl, V. Voytsekhivskiy, A. Mohdaly, Y. Shevchenko, Antioxidant activity of apple peels. Mechanics and technology, 2016, No. 2 (52), pp. 61-65.

[10] S.A. Kishkovskaya, A.S. Lukanin, E.V. Sycheva, Study of Schizosaccharomyces yeast influence on aromatic complex and organoleptic characteristics of cider materials, Magarach. Wine growing and winemaking, No. 1, pp. 27-28, 2015.

[11] Satora, Pawel; Semik-Szczurak, Dorota; Tarko, Tomasz; с соавторами Influence of Selected Saccharomyces and Schizosaccharomyces Strains and Their Mixed Cultures on Chemical Composition of Apple Wines, JOURNAL OF FOOD SCIENCE, V. 83, Issue 2, pp. 424-431, published: FEB 2018.

[12] Staples Martina, Poechlinger Georg, Goessinger Manfred, Impact of different yeasts on organoleptic parameters of apple wine, MITTEILUNGEN KLOSTERNEUBURG, V. 66, Issue 3, oo. 245-254, 2016.

[13] Peng Bangzhu, Li Fuling, Cui Lu, Effects of Fermentation Temperature on Key Aroma Compounds and Sensory Properties of AppleWine, Journal of food science, V. 80, Issue 12, pp. 2937-2943, DEC 2015.

[14] Kumar Vikas, Joshi Vinod K., Vyas Gitanjali, et al., Effect of Different Types of Fermentation (Inoculated and Natural Fermentation) On the Functional Properties of Apple Tea Wine, RESEARCH JOURNAL OF PHARMACEUTICAL BIOLOGICAL AND CHEMICAL SCIENCES, V. 6, Issue 3, pp. 847-854, published: MAY-JUN 2015.

[15] Zardo Danianni Marinho, Alberti Aline, Campos Dantas Ana Paula, Effect of the processing in the phenolic compounds content and antioxidant activity in applewine, SEMINA-CIENCIAS AGRARIAS, V. 29, Issue 4, pp. 829-838, published: OCT-DEC 2008.

[16] GOST P 51433-99 Fruit and vegetable juice. Determining the content of soluble solids via refractometer, Moscow: Standartinform, 2008, pp. 7.

[17] GOST P 51434-99 Fruit and vegetable juice. Determining the content of titrable acidity, Moscow: Standartinform, 2006, pp. 7.

[18] P.A. Fedina, A.Ya. Yashin, N.I. Chernousova, Definition of antioxidants in plant products by amperometrical method, Chemistry of vegetable raw materials, No. 2, pp. 91-97, 2010.

[19] GOST 8756.13-87 Products of fruit and vegetable processing. Methods to determine the sugar content, Moscow: Standartinform, 2010, pp. 9.

[20] O.Yu. Koltysheva, S.A. Sokolova, O.V. Dyakonova, A.A. Kolobayeva, O.A. Kotik, Comparison of spectrophotometric and permanganatometry 
determination of tannin content in apple juice for cider production, International student's scientific bulletin, 2018, No. 3-2, pp. 250-253.

[21] G.S. Kachmazov, Yeast of fermentation industry: study manual, $\mathrm{SPb}$ : Lan publishing house, 2012, pp. 224

[22] V.M. Poznyakovsky, V.A. Pomozova, T.F. Kiselyova, L.V. Permyakova, Expertise of beverages. Quality and safety: study manual, $7^{\text {th }}$ edition, revised and extended, Novosibirsk: Publishing house of Siberian University, 2007, pp. 407.

[23] Yu.P. Grachev, Yu.M. Plaksin, Mathematical methods of experimental design, M.: DeLi print, 2005, pp. 296 